\title{
Primary intraosseous osteolytic meningioma: a case report and review of the literature
}

\author{
Sae Min Kwon ${ }^{1,2}$, Yong Ko ${ }^{1 *}$ (D) and Seong Sik Bang ${ }^{3}$
}

\begin{abstract}
Background: Primary intraosseous meningioma is a subset of extradural meningioma that arises in the bone, and only a few cases have been reported to date.

Case presentation: An 80-year-old man presented with decreased hearing on the right side accompanied by a disturbance of balance 10 months prior to admission. Magnetic resonance imaging revealed an $8 \times 7 \mathrm{~cm}$ osteolytic mass in the right posterior fossa related to the petrous bone, with extension to the cervical region. During surgery, the tumor was found to be located extradurally, with no invasion of the dura. The tumor was removed entirely, apart from a small portion around the jugular foramen to avoid lower cranial nerve injury.

Conclusion: The final diagnosis was primary intraosseous osteolytic meningioma with atypical pathology. Here, we report a rare case of an osteolytic skull lesion in the skull base not invading the dura and with extensive bone destruction.
\end{abstract}

Keywords: Intraosseous, Meningioma, Osteolysis

\section{Background}

Meningiomas are common intradural lesions that arise from the arachnoid cap cells of the arachnoid layer. In contrast, primary extradural meningioma is a relatively rare entity, accounting for less than $2 \%$ of all meningiomas $[1,2]$. They may arise from other locations, such as the skin, orbit, nasopharynx, and neck [3-5]. Primary intraosseous meningioma, which arises in the bone, is a subset of primary extradural meningioma, and only a few cases have been reported $[1,3]$. Here, we report a recent case of primary intraosseous osteolytic meningioma with extension to the cervical region which was successfully removed.

\section{Case presentation}

An 80-year-old man presented with a progressive decrease in hearing on the right side accompanied by dizziness and disturbance of balance 10 months prior to admission. The neurological examination revealed right

\footnotetext{
* Correspondence: koy8497@hanyang.ac.kr

${ }^{1}$ Departments of Neurosurgery, College of Medicine, Hanyang University, 17 Haengdang-dong, Seongdong-gu, 133-792 Seoul, Republic of Korea Full list of author information is available at the end of the article
}

hypoglossal nerve palsy. Audiometry documented complete sensorineural hearing loss on the right side.

Skull $x$-ray and cranial computed tomography (CT) scans showed a large osteolytic lesion with bone destruction, including the temporal bone, occipital bone, clivus, jugular foramen, and hypoglossal canal (Fig. 1a and b). Magnetic resonance imaging (MRI) revealed an $8 \times 7 \mathrm{~cm}$ homogeneous enhancing mass in the right posterior fossa related to the petrous part of the temporal bone, with extension to the cervical region (Fig. 1c). The cerebellum was displaced, and definite brain invasion was not seen. The preoperative diagnosis was a temporal bone origin malignancy such as squamous cell carcinoma or meningioma with invasion of the petrous bone.

The patient underwent surgery to obtain a pathological diagnosis and for complete removal of the mass. A $\mathrm{C}$-shaped postauricular skin incision was made that extended to the neck. The scalp was reflected anteriorly, and the mass infiltrating the subcutaneous tissue was exposed. The lesion appeared as a firm gray mass that had destroyed the temporal and occipital bones. The dura was intact with no invasion, and the lesion 


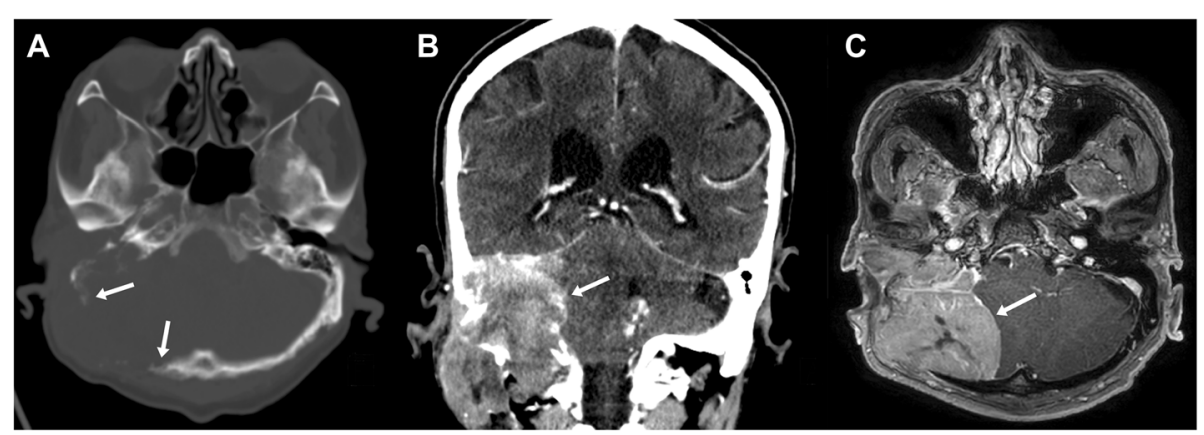

Fig. 1 Preoperative imaging. Axial computed tomography (CT) scan with bone window (a) shows a destructive osteolytic mass lesion in the right temporal-posterior fossa region. Coronal $C T$ scan $(\mathbf{b})$ and magnetic resonance imaging (c) revealed an $8 \times 7 \mathrm{~cm}$ homogenous mass extending to the cervical region

was easily peeled off. For the cervical part of the tumor, the major vessels were secured inferiorly, and the mass was removed up to the skull base. The tumor was removed entirely, except for a small portion around the jugular foramen to avoid lower cranial nerve injury. Finally, the large empty space was filled with a sternocleidomastoid muscle flap (Fig. 2). There were no neurological deficits after surgery.

Histopathological studies confirmed a WHO (World Health Organization) grade II atypical meningioma with up to 6 mitoses per 10 high-power fields (Fig. 3). The Ki-67 proliferation index was $15 \%$. The results of immunohistochemical staining are provided in Additional file 1: Figure S1.

\section{Discussion and conclusions}

Primary intraosseous meningiomas are rare cranial lesions that arise from the bone, and they represent the most common type of primary extradural meningiomas [1-3]. The majority of intraosseous meningiomas are osteoblastic and cause hyperostosis, which may mimic fibrous dysplasia. In contrast, and more rarely, they may present as an osteolytic skull lesion [6, 7]. Reportedly, less than $20 \%$ of intraosseous meningiomas are osteolytic [8].

Primary extradural meningiomas are most commonly found in skull convexities, the paranasal sinus, and the middle ear but rarely in the skull base. Liu et al. reported 170 cases of extradural meningiomas in the head, and only 5.8\% were located in the skull base [9]. Notably, there are few reports of osteolytic intraosseous meningiomas in the skull base. To date, 50 cases of osteolytic subtypes (including the present case) have been reported in the English literature (Table 1). Of these, only seven were located in the skull base, and all but two originated from the petrous bone.

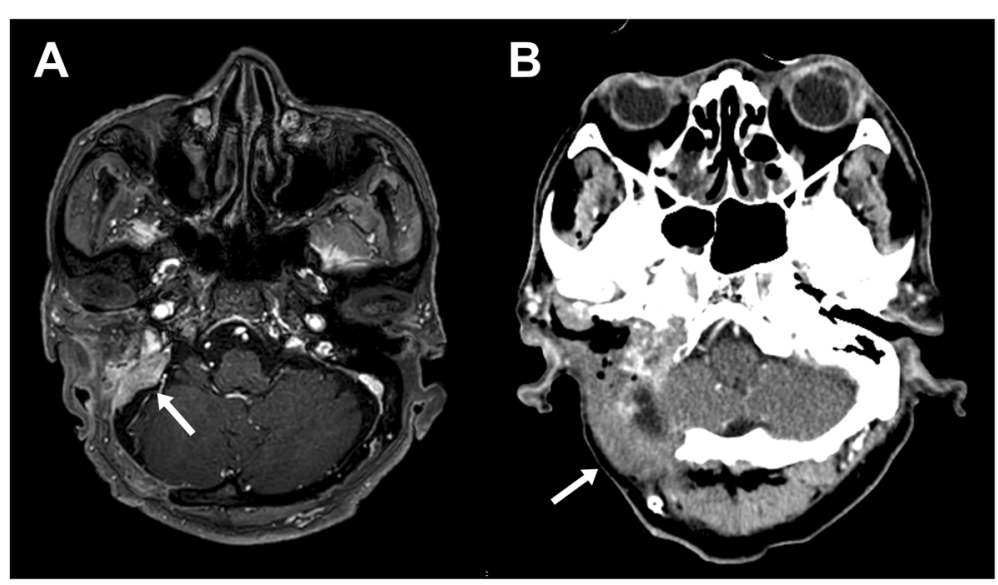

Fig. 2 Postoperative magnetic resonance imaging (a) shows a small residual tumor around the jugular foramen, and computed tomography scan (b) demonstrates the sternocleidomastoid muscle which fills the tumor removal space 


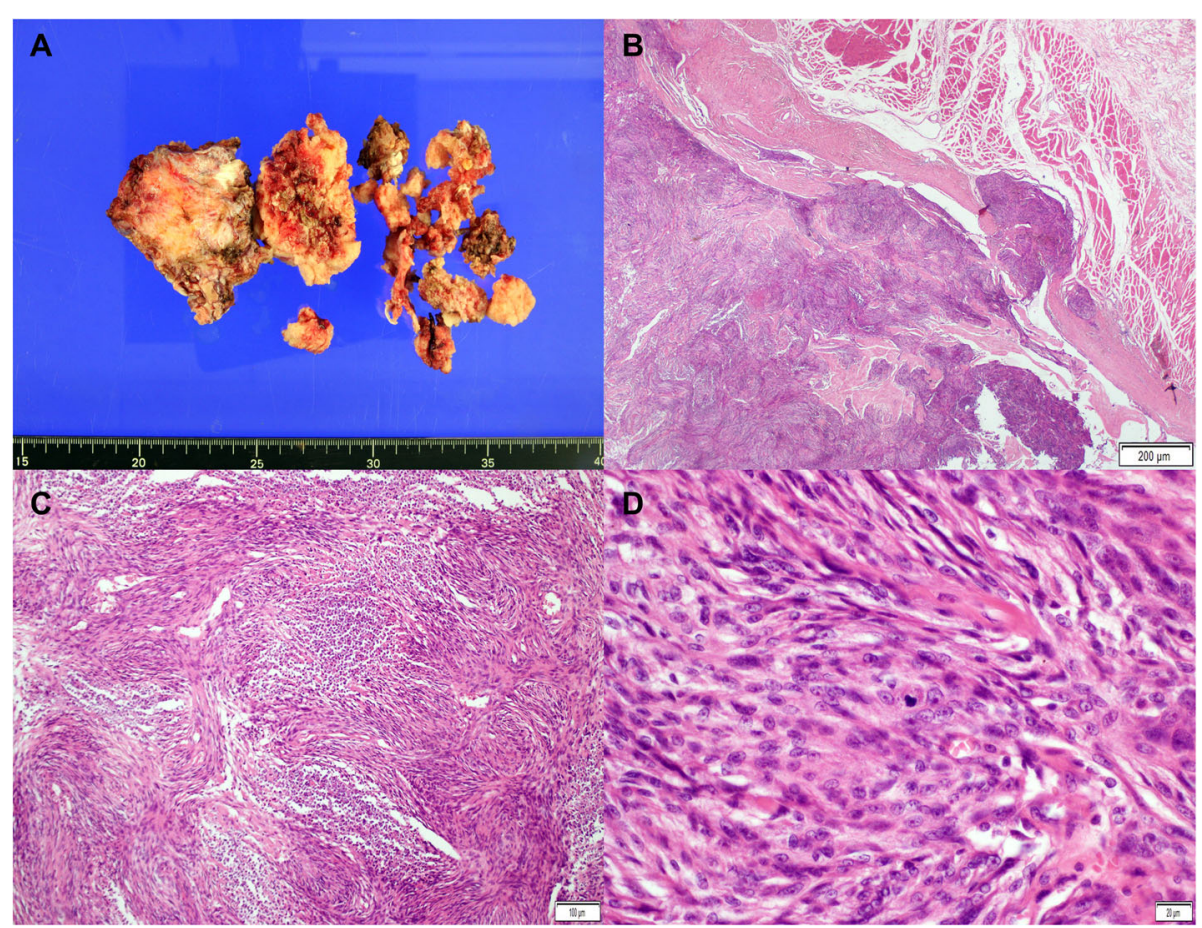

Fig. 3 Histopathologic findings of atypical meningioma. The fragmented specimen (a) is seen as grayish-white solid masses. On microscopic examination, the tumor infiltrated the adjacent soft tissue (b, hematoxylin and eosin [H\&E] stain, $\times 20$, scale bar $=200 \mu m$ ) and showed a whorled appearance and multifocal necrosis (c, H\&E stain, $\times 100$, scale bar $=100 \mu \mathrm{m}$ ). The tumor cells are composed of spindle cells with prominent nucleoli and ill-defined cytoplasm. Many mitoses are visible (d, H\&E stain, $\times 400$, scale bar $=20 \mu \mathrm{m})$

The exact origin of extradural meningiomas is unclear, but several theories have been proposed. Their unusual locations are assumed to be the result of the aberrant differentiation or misplacement of undifferentiated mesenchymal stem cells [51]. Alternatively, extradural meningiomas may arise from differentiated arachnoid cap cells associated with blood vessels or nerves traversing the skull [52, 53]. Another theory proposes that they originate from arachnoid cap cells that get trapped in the cranial sutures during embryogenesis or molding of the cranium at birth [20, 21, 54]. Trauma with skull fracture has also been proposed as a causative factor of some extradural meningiomas, suggesting direct dural entrapment within bone fragments at the time of trauma [55].

The osteolytic subtype of intraosseous meningiomas is often misdiagnosed as a primary or secondary bone tumor due to its radiological appearance. The differential diagnosis of a solitary osteolytic skull lesion includes hemangioma, chondroma, chondrosarcoma, eosinophilic granuloma, epidermoid cyst, giant cell tumor, myeloma, and metastatic skull tumor $[6,23,33]$.

Primary extradural meningiomas were practically classified according to their location by Lang and colleagues (Table 2) [3]. Therefore, intraosseous meningiomas could be considered Type II or Type III extradural meningiomas. Based on this classification, the present case falls into the type IIIB category due to the presence of extracalvarial extension. This classification is helpful in predicting the risk of tumor recurrence. The IIC and IIIC subtypes rarely recur after complete resection, whereas the IIB and IIIB subtypes have a reported lifetime risk of recurrence of $26 \%$ [3].

Histopathological features are also important factors affecting tumor recurrence and prognosis. Recurrence was noted in $22 \%$ of benign intraosseous meningiomas in the literature, while it was reportedly $33 \%$ in cases of tumors with atypical or malignant pathology. In addition, aggressive atypical or malignant meningiomas had a significantly higher mortality of $29 \%$ compared to tumors with benign features (4.8\%) [3]. Osteolytic meningiomas may have a higher incidence of atypical or malignant features [6]. In previous reports, benign features were reported in $87-89 \%$ of all extradural meningiomas, whereas in our literature review of osteolytic intraosseous meningiomas, $26 \%$ of cases were WHO grade II or III $[3,8]$. 
Table 1 Reports of primary intraosseous osteolytic meningiomas

\begin{tabular}{|c|c|c|c|c|}
\hline Reference, year & Sex/age & Location & Type & Pathology \\
\hline Klein et al., 1975 [10] & $F / 66$ & Parietal & IIIC & Meningothelial \\
\hline $\begin{array}{l}\text { McWhorter et al., } 1976 \\
\text { [11] }\end{array}$ & $M / 42$ & Temporal & $\| C$ & Benign \\
\hline Palma et al., 1977 [12] & $M / 18$ & Frontal & $\| \mathrm{IIC}$ & Fibroblastic \\
\hline Pearl et al., 1979 [13] & $F / 44$ & Frontal & $\| C$ & Meningothelial \\
\hline $\begin{array}{l}\text { Ohaegbulam et al., } \\
1979 \text { [14] }\end{array}$ & $M / 31$ & Frontal & $\| \mathrm{IIC}$ & Fibroblastic \\
\hline Young et al., 1983 [15] & $M / 71$ & Frontal & $\| C$ & Benign \\
\hline $\begin{array}{l}\text { Kaneko et al., } 1988 \\
\text { [16] }\end{array}$ & $\mathrm{F} / 71$ & Frontoparietal & $\| \mathrm{IIC}$ & Fibroblastic \\
\hline Lee et al., 1988 [17] & $F / 71$ & Frontoparietal & $\| C$ & Malignant \\
\hline Oka et al., 1989 [18] & $F / 79$ & Frontoparietal & $\| I C$ & Transitional \\
\hline $\begin{array}{l}\text { Ammirati et al., } 1990 \\
\text { [19] }\end{array}$ & $M / 21$ & Petrous & $\| \mathrm{B}$ & Benign \\
\hline Kulali et al., 1991 [20] & $\mathrm{M} / 50$ & Occipital & $\| \mathrm{IIC}$ & Transitional \\
\hline Ito et al., 1992 [21] & $\mathrm{F} / 72$ & Frontoparietal & $\| C$ & Meningothelial \\
\hline Fujita et al., 1993 [22] & $M / 42$ & Petrous & $\| \mathrm{B}$ & Malignant \\
\hline $\begin{array}{l}\text { Ghobashy and Tobler, } \\
1994 \text { [23] }\end{array}$ & $F / 65$ & Frontal & $\| C$ & Transitional \\
\hline $\begin{array}{l}\text { Parington et al., } 1995 \\
\text { [24] }\end{array}$ & $\mathrm{F} / 84$ & Frontotemporal & $\| \mathrm{IIC}$ & Atypical \\
\hline Levin et al., 1995 [25] & N/A & Calvaria & N/A & N/A \\
\hline $\begin{array}{l}\text { Kuzeyli et al., } 1996 \\
\text { [26] }\end{array}$ & $M / 6$ & Temporal & $\| C$ & Meningothelial \\
\hline $\begin{array}{l}\text { Changhong et al., } \\
1997 \text { [27] }\end{array}$ & $\mathrm{F} / 42$ & Occipital & $\| C$ & Malignant \\
\hline \multirow{3}{*}{$\begin{array}{l}\text { Muthukumar et al., } \\
1997 \text { [28] }\end{array}$} & $M / 55$ & Parietal & $\| I I C$ & Meningothelial \\
\hline & $M / 50$ & Temporoparietal & $\| C$ & Meningothelial \\
\hline & $M / 60$ & Frontal & $\| I I C$ & Meningothelial \\
\hline Kudo et al., 1998 [29] & $F / 56$ & Parietooccipital & $\| I C$ & Meningothelial \\
\hline $\begin{array}{l}\text { Okamoto et al., } 2000 \\
\text { [30] }\end{array}$ & $\mathrm{F} / 78$ & Parietal & $\| C$ & Microcystic \\
\hline $\begin{array}{l}\text { Yamazaki et al., } 2001 \\
\text { [31] }\end{array}$ & $M / 62$ & Occipital & $\| \mathrm{B}$ & Meningothelial \\
\hline Rosahl et al., 2004 [32] & $M / 38$ & Petrous & $\| B$ & Meningothelial \\
\hline $\begin{array}{l}\text { Tokgoz et al., } 2005 \\
\text { [33] }\end{array}$ & $\mathrm{M} / 44$ & Frontoparietal & IIIC & Chordoid \\
\hline \multirow{5}{*}{$\begin{array}{l}\text { Bassiouni et al., } 2006 \\
{[34]}\end{array}$} & $M / 47$ & Parietal & $\| I I C$ & Benign \\
\hline & $F / 46$ & Temporal & $\| C$ & Meningothelial \\
\hline & $F / 57$ & Parietal & $\| C$ & Fibroblastic \\
\hline & $F / 62$ & Frontal & $\| C$ & Atypical \\
\hline & $M / 34$ & temporal & $\| I I C$ & Meningothelial \\
\hline $\begin{array}{l}\text { Al-Khawaja et al., } \\
2007 \text { [35] }\end{array}$ & $\mathrm{M} / 50$ & Parietal & $\| C$ & Meningothelial \\
\hline $\begin{array}{l}\text { Sheikhrezaie et al., } \\
2009 \text { [36] }\end{array}$ & $M / 62$ & Frontoparietal & $\| I I C$ & Benign \\
\hline Yener et al., 2009 [37] & $M / 78$ & Parietal & $\| C$ & Meningothelial \\
\hline Hong et al., 2010 [38] & $M / 52$ & Parietal & N/A & Benign \\
\hline
\end{tabular}

Table 1 Reports of primary intraosseous osteolytic meningiomas (Continued)

\begin{tabular}{|c|c|c|c|c|}
\hline Reference, year & Sex/age & Location & Type & Pathology \\
\hline & $M / 73$ & Occipital & N/A & Anaplastic \\
\hline \multirow[t]{2}{*}{ Kim et al., 2012 [39] } & $M / 68$ & Parietal & $I I I C$ & Atypical \\
\hline & $\mathrm{F} / 74$ & Frontal & $\| I C$ & Papillary \\
\hline $\begin{array}{l}\text { Akhaddar and } \\
\text { Ennouali, } 2014 \text { [40] }\end{array}$ & $F / 37$ & Frontal & $\| C$ & Meningothelia \\
\hline Tang et al., 2014 [41] & $F / 82$ & Parietal & $\| C$ & Meningothelia \\
\hline $\begin{array}{l}\text { Yun and Lee, } 2014 \\
\text { [42] }\end{array}$ & $F / 65$ & Frontal & $\| I I C$ & Atypical \\
\hline Kim et al., 2014 [43] & $F / 44$ & Sphenoid & $\| \mathrm{II}$ & Transitional \\
\hline $\begin{array}{l}\text { Bujok and Bienioszek, } \\
2014 \text { [44] }\end{array}$ & $F / 59$ & Frontal & $\| C$ & Microcystic \\
\hline Kwon et al., 2015 [45] & $M / 69$ & Parietal & IIIC & Meningothelia \\
\hline Hong et al., 2015 [46] & $M / 61$ & Frontoparietal & $\| C$ & Benign \\
\hline $\begin{array}{l}\text { Ben Nsir et al., } 2016 \\
\text { [47] }\end{array}$ & $M / 42$ & Petrous & $\| \mathrm{B}$ & Clear cell \\
\hline $\begin{array}{l}\text { Bohara et al., } 2016 \\
\text { [48] }\end{array}$ & $M / 38$ & Parietal & $\| I I C$ & Atypical \\
\hline Mouri et al., 2017 [49] & $F / 76$ & Frontal & $\| I C$ & Transitional \\
\hline $\begin{array}{l}\text { Richardson et al., } \\
2017 \text { [50] }\end{array}$ & $M / 23$ & Frontal & $\| C$ & Benign \\
\hline Present case & $\mathrm{M} / 80$ & Petrous & $\| \mathrm{B}$ & Atypical \\
\hline
\end{tabular}

Wide surgical excision is the main treatment for extradural meningiomas, and it is potentially curative if complete resection is achieved [6, 7]. In the present case, a small portion of the tumor near the jugular foramen could not be removed due to the possibility of cranial nerve injury. In the case of skull base lesions that cannot be totally resected, decompression of vital neural structures is performed.

In conclusion, we performed surgical treatment for a rare case of primary osteolytic intraosseous meningioma in the skull base with extension to the cervical area. The histopathologic diagnosis was atypical meningioma. If possible, complete resection is the treatment of choice, and serial follow-up should be done to confirm recurrence or progression.

Table 2 Primary extradural meningioma classification by Lang et al. 2000 [3]

\begin{tabular}{lll}
\hline Type & Description & Subtype \\
\hline I & Purely extracalvarial with no bony attachment & \\
& Purely calvarial & B (skull base) \\
III & Calvarial with extracalvarial extension & C (convexity) \\
& & B (skull base) \\
& C (convexity) \\
\hline
\end{tabular}




\section{Additional file}

Additional file 1: Figure S1. Immunohistochemical staining results. The tumor showed a wild-type p53 pattern $(A, \times 200)$ and exhibited strong cytoplasmic expression of $\beta$-catenin $(B, \times 200)$. Some tumor cells exhibited weak membranous expression of EGFR $(C, \times 200)$. The tumor was negative for $\mathrm{BCl}-2(\mathrm{D}, \times 200)$. The tumor shows membrane and cytoplasmic immunopositivity for EMA $(E, \times 200)$ and negative for $S-100$ protein $(F, \times 200)$. Vimentin is diffusely expressed in the cytoplasm of tumor cells $(\mathrm{G}, \times 200)$. The Ki-67 proliferation index is estimated to be approximately $15 \%(H, \times 200)$. Scale bar $=100 \mu \mathrm{m}$. (DOCX $8214 \mathrm{~kb})$

\section{Abbreviations}

CT: Computed tomography; MRI: Magnetic resonance imaging; WHO: World Health Organization

\section{Acknowledgements}

Not applicable.

\section{Authors' contributions}

SMK collected data and drafted the manuscript. YK critically revised the manuscript and supervised the study. SSB performed the pathological analysis. All authors revised the manuscript and approved the final version.

\section{Funding}

Not applicable.

\section{Availability of data and materials}

Not applicable.

\section{Ethics approval and consent to participate}

This study was approved by the institutional review board of Hanyang University Medical Center.

\section{Consent for publication}

Written informed consent was obtained from the patient for publication of this Case Report and any accompanying images. A copy of the signed consent form is available for review by the Editor of this journal.

\section{Competing interests}

The authors declare that they have no competing interests.

\section{Author details}

'Departments of Neurosurgery, College of Medicine, Hanyang University, 17 Haengdang-dong, Seongdong-gu, 133-792 Seoul, Republic of Korea.

${ }^{2}$ Department of Neurosurgery, Keimyung University School of Medicine, 1095 Dalgubeol-daero, Dalseo-gu, Daegu 42601, Republic of Korea. ${ }^{3}$ Departments of Pathology, College of Medicine, Hanyang University, 17 Haengdang-dong, Seongdong-gu, 133-792 Seoul, Republic of Korea.

Received: 26 February 2018 Accepted: 3 July 2019

Published online: 23 July 2019

\section{References}

1. Agrawal V, Ludwig N, Agrawal A, Bulsara KR. Intraosseous Intracranial Meningioma. Am J Neuroradiol. 2007;28:314-5.

2. Muzumdar DP, Vengsarkar US, Bhatjiwale MG, Goel A. Diffuse calvarial meningioma: a case report. J Postgrad Med. 2001:47:116.

3. Lang FF, Macdonald OK, Fuller GN, DeMonte F. Primary extradural meningiomas: a report on nine cases and review of the literature from the era of computerized tomography scanning. J Neurosurg. 2000;93:940-50.

4. Nicolay S, De Foer B, Bernaerts A, Van Dinther J, Parizel PM. A case of a temporal bone meningioma presenting as a serous otitis media. Acta Radiol Short Rep. 2014;3:2047981614555048.

5. Hoye SJ, Hoar CS, Murray JE. Extracranial meningioma presenting as a tumor of the neck. Am J Surg. 1960;100:486-9.

6. Elder JB, Atkinson R, Zee C-S, Chen TC. Primary intraosseous meningioma. Neurosurg Focus. 2007;23:E13.

7. Crawford TS, Kleinschmidt-DeMasters BK, Lillehei KO. Primary intraosseous meningioma. Case report. J Neurosurg. 1995;83:912-5.
8. Mattox A, Hughes B, Oleson J, Reardon D, McLendon R, Adamson C. Treatment recommendations for primary extradural meningiomas. Cancer. 2011;117:24-38.

9. Liu $Y$, Wang $H$, Shao $H$, Wang $C$. Primary extradural meningiomas in head: a report of 19 cases and review of literature. Int J Clin Exp Pathol. 2015;8:5624.

10. Klein EW, Farhat SM, Hoskins PA, Colvin JT. Radionuclide cerebral angiographic evaluation of a diploic extracranial meningioma: case report. Nucl Med Off Publ Soc Nucl Med. 1975;16:833-4.

11. McWhorter JM, Ghatak NR, Kelly DL. Extracranial meningioma presenting as lytic skull lesion. Surg Neurol. 1976;5:223-4.

12. Palma L, Mercuri S, Ferrante L. Epidural calvarial meningioma. Surg Neurol. 1977:8:315-8.

13. Pearl GS, Takei Y, Parent AD, Boehm WM. Primary intraosseous meningioma presenting as a solitary osteolytic skull lesion: case report. Neurosurgery. 1979;4:269-70

14. Ohaegbulam SC. Ectopic epidural calvarial meningioma. Surg Neurol. 1979; 12:33-5.

15. Young PH. Solitary subcutaneous meningioma appearing as an osteolytic skull defect. South Med J. 1983;76:1039-40.

16. Kaneko F, Takase K, Nishiyama K, Kusaka K, Morizumi H, Matsumoto K. Report of a case of intraosseous meningioma. No Shinkei Geka. 1988;16: 197-202.

17. Lee WH, Tu YC, Liu MY. Primary intraosseous malignant meningioma of the skull: case report. Neurosurgery. 1988;23:505-8.

18. Oka K, Hirakawa K, Yoshida S, Tomonaga M. Primary calvarial meningiomas. Surg Neurol. 1989;32:304-10.

19. Ammirati M, Mirzai S, Samii M. Primary intraosseous meningiomas of the skull base. Acta Neurochir (Wien). 1990;107:56-60.

20. Kulali A, Ilçayto R, Rahmanli O. Primary calvarial ectopic meningiomas. Neurochirurgia (Stuttg). 1991;34:174-7.

21. Ito $\mathrm{H}$, Takagi $\mathrm{H}$, Kawano $\mathrm{N}$, Yada K. Primary intraosseous meningioma: case report. J Neurooncol. 1992;13:57-61.

22. Fujita T, Nakagawa H, Tsuruzono K, Izumoto S, Kadota T, Wada A. Extradural temporal meningioma directly extended to cervical bone--case report. Neurol Med Chir (Tokyo). 1993:33:458-62.

23. Ghobashy A, Tobler W. Intraosseous calvarial meningioma of the skull presenting as a solitary osteolytic skull lesion: case report and review of the literature. Acta Neurochir (Wien). 1994;129:105-8.

24. Partington MD, Scheithauer BW, Piepgras DG. Carcinoembryonic antigen production associated with an osteolytic meningioma. Case report. J Neurosurg. 1995;82:489-92.

25. Levin M, Wertheim SE, Klein E, Lowry J. Unusual lytic intraosseous meningioma. J Neuroimaging Off J Am Soc Neuroimaging. 1995:5:247-8.

26. Kuzeyli K, Duru S, Baykal S, Usul H, Ceylan S, Aktürk F. Primary intraosseous meningioma of the temporal bone in an infant. A case report. Neurosurg Rev. 1996;19:197-9.

27. Changhong L, Naiyin C, Yuehuan G, Lianzhong Z. Primary intraosseous meningiomas of the skull. Clin Radiol. 1997;52:546-9.

28. Muthukumar N. Primary calvarial meningiomas. Br J Neurosurg. 1997:11: 388-92.

29. Kudo H, Maeda S, Takamoto T, Tamaki N. Intraosseous meningioma with a dural defect. Neurol Med Chir (Tokyo). 1998;38:229-31.

30. Okamoto S, Hisaoka M, Aoki T, Kadoya C, Kobanawa S, Hashimoto H. Intraosseous microcystic meningioma. Skeletal Radiol. 2000;29:354-7.

31. Yamazaki T, Tsukada A, Uemura K, Satou H, Tsuboi K, Nose T. Intraosseous meningioma of the posterior fossa--Case report. Neurol Med Chir (Tokyo). 2001:41:149-53.

32. Rosahl SK, Mirzayan M-J, Samii M. Osteolytic intra-osseous meningiomas: illustrated review. Acta Neurochir (Wien). 2004;146:1245-9.

33. Tokgoz N, Oner YA, Kaymaz M, Ucar M, Yilmaz G, Tali TE. Primary intraosseous meningioma: CT and MRI appearance. AJNR Am J Neuroradiol. 2005:26:2053-6.

34. Bassiouni H, Asgari S, Hübschen U, König H-J, Stolke D. Dural involvement in primary extradural meningiomas of the cranial vault. J Neurosurg. 2006;105:51-9

35. Al-Khawaja D, Murali R, Sindler P. Primary calvarial meningioma. J Clin Neurosci Off J Neurosurg Soc Australas. 2007;14:1235-9.

36. Sheikhrezaie A, Meybodi AT, Hashemi M, Shafiee S. Primary intraosseous osteolytic meningioma of the skull: a case report. Cases J. 2009;2:7413. 
37. Yener U, Bayrakli F, Vardereli E, Sav A, Peker S. Intradiploic meningioma mimicking calvarial metastasis: case report. Turk Neurosurg. 2009;19:297301.

38. Hong B, Hermann EJ, Klein R, Krauss JK, Nakamura M. Surgical resection of osteolytic calvarial lesions: clinicopathological features. Clin Neurol Neurosurg. 2010;112:865-9.

39. Kim H, Jung T-Y, Kim I-Y, Lee J-K. Two cases of primary osteolytic intraosseous meningioma of the skull metastasizing to whole skull and the spine. J Korean Neurosurg Soc. 2012;51:151-4.

40. Akhaddar A, Ennouali H. Intraosseous extradural meningioma of the frontal bone. Pan Afr Med J. 2014;17:69.

41. Tang V, Lam M, Lai A. Intraosseous meningioma mimicking a metastasis. BMJ Case Rep. 2014;2014.

42. Yun J-H, Lee S-K. Primary osteolytic intraosseous atypical meningioma with soft tissue and dural invasion: report of a case and review of literatures. J Korean Neurosurg Soc. 2014;56:509-12.

43. Kim HS, Kim SH, Kim HJ, Kang SW, Kim SJ, Lee JH, et al. Primary Benign Intraosseous Meningioma on (18)F-FDG PET/CT Mimicking Malignancy. Nucl Med Mol Imaging. 2014;48:153-6.

44. Bujok J, Bienioszek M. Microcystic variant of an intraosseous meningioma in the frontal area: a case report. Case Rep Neurol Med. 2014;2014:527267.

45. Kwon SY, Shin HS, Kim TH, Kim HJ. Primary Intraosseous Osteolytic Meningioma of the Skull Mimicking Scalp Mass: A Case Report and Review of Literature. Brain Tumor Res Treat. 2015;3:151-5.

46. Hong SC, Woon K, O'Keeffe B. Brain mushroom: A case of osteolytic intraosseous meningioma with transcalvaria herniation. $\mathrm{Br} J$ Neurosurg. 2015;29:876-8.

47. Ben Nsir A, Ben Hamouda K, Hammedi F, Kilani M, Hattab N. Osteolytic clear cell meningioma of the petrous bone occurring 36 years after posterior cranial fossa irradiation: Case report. Neurol Neurochir Pol. 2016;50:297-302.

48. Bohara S, Agarwal S, Khurana N, Pandey PN. Primary intraosseous atypical inflammatory meningioma presenting as a lytic skull lesion: Case report with review of literature. Indian J Pathol Microbiol. 2016:59:386-8.

49. Mouri G, Suzuki H, Hatazaki S, Matsubara T, Taki W. Skull Meningioma Associated with Intradural Cyst: A Case Report. Clin Med Insights Case Rep. 2017;10:1179547617738231

50. Richardson TE, Georgescu M-M, Kapur P, Hwang H, Barnett SL, Raisanen JM, et al. Unusual skull tumors with psammomatoid bodies: a diagnostic challenge. Clin Neuropathol. 2017;36(2017):114-20.

51. Shuangshoti S, Netsky MG, Fitz-Hugh GS. Parapharyngeal meningioma with special reference to cell of origin. Ann Otol Rhinol Laryngol. 1971;80:464-73.

52. Perzin KH, Pushparaj N. Nonepithelial tumors of the nasal cavity, paranasal sinuses, and nasopharynx. A clinicopathologic study. XIII: Meningiomas. Cancer. 1984:54:1860-9.

53. Pompili A, Caroli F, Cattani F, lachetti M. Intradiploic meningioma of the orbital roof. Neurosurgery. 1983;12:565-8.

54. Azar-Kia B, Sarwar M, Marc JA, Schechter MM. Intraosseous meningioma. Neuroradiology. 1974;6:246-53

55. Turner OA, Laird AT. Meningioma with traumatic etiology. Report of a case. J Neurosurg. 1966;24:96-8.

\section{Publisher's Note}

Springer Nature remains neutral with regard to jurisdictional claims in published maps and institutional affiliations.

Ready to submit your research? Choose BMC and benefit from:

- fast, convenient online submission

- thorough peer review by experienced researchers in your field

- rapid publication on acceptance

- support for research data, including large and complex data types

- gold Open Access which fosters wider collaboration and increased citations

- maximum visibility for your research: over $100 \mathrm{M}$ website views per year

At $\mathrm{BMC}$, research is always in progress.

Learn more biomedcentral.com/submissions 